\title{
DISKUSSIE OOR DIE KERKLIED
}

\section{BR. T. G. VAN WYK ANTWOORD OP DR. KEMPFF SE} BESPREKING VAN: EK SING 'N LOFLIED BY MY SNARE

Lees 'n mens dr. Kempff se resensie oor „Ek sing 'n lofsang by my snare", kom jy tot die gevolgtrekking dat hy nie die hele boek gelees het nie, of hier en daar gedeeltes gegryp het en daarmee op loop gesit het. Indien hy die hele boek gelees het, sou hy seker nie sommige vrae gestel het, wat wel in die boek beantwoord word nie. Voorbeeld hiervan is:

„Die Heilige Gees het die boek van die Psalms vir tempelgebruik bestem" (p. 6). Dr. Kempff se kommentaar hierop is: „Hiervoor word geen bewys uit die Skrif gegee nie, maar dit is 'n skarnierpunt vir net-Psalms-in-die-erediens". Het dr. Kempff dan nie gelees wat op bladsy 23 in die laaste paragraaf van Totius aan. gehaal word nie, nl. „Jesus sing as Maker van die Psalms.” Maar ons moet nog dieper grawe. In die derde plek wil ons aantoon dat Jesus self die maker is van sy lied. Hoe is dit moontlik? vra u. Die Psalms is tog lank, bale lank voor die vleeswording van Christus gedig: hoe kan hy dan die maker daarvan wees? Hier kom die Apostel Petrus ons te hulp deurdat hy sê dat die Gees van Christus in die profete was wat voor hom geprofeteer het van Sy lyde en die werklikheid daarvan (1 Petrus 1:12). Maar ook Dawid en al die heilige sangers was profete. Die lof wat hulle aangestem het was dus vanweë die drywing van die Gees van Christus. Inwendig het Hy hulle toegefluister wat en hoe hulle moes sing."

Dit is eienaardig dat dr. Kempff nie ook vir prof. P. W. Buys te lyf gaan met sy aanhaling oor die Psalms en die Heilige Gees in die eerste twee paragrawe op bladsy 2 nie. Of wil dr. Kempff op grond van die Skrif ontken dat die Heilige Gees die boek van die Psalms vir tempelgebruik bestem het? Indien dr. Kempff se kritiek korrek is, sou ek graag dieselfde wou beweer wanneer hy sê: ,Tog moet ons erken dat dit juis Christus is wat die Nuwe Testament, met sy liedere, aan sy kerk gegee het." Dit klink tog ook so na 'n skarnierpunt argument vir Skrifberymings in die erediens, want die broeder staaf nie sy bewering met die Skrif nie. Indien die Heilige Gees dit nie gedoen het nie (soos $\mathrm{K}$. my bewering van die Psalms weerspreek) is $\mathrm{K}$. se bewering dat Christus in die Nuwe Testament sy liedere aan sy kerk gegee het, onjuis, want die Nuwe Testament het lank na Christus gevolg, soos die Ou Testament lank voor Hom gewees het.

Tweedens beweer dr. K., ek haal aan: „Calvyn bring in 1593 ' $n$ bundeltjie uit sodat die gemeente self kan sing. Daarin is 18 Psalms en 3 andere - terwyl Van Wyk van 'n totaal van 18 praat (p. 89). Ek kry die indruk dat dr. K. my verdag wil maak by die lesers, want dit gaan nie eintlik oor die 18 wat Psalms was nie, maar oor die 3 andere. Oor die 18 kan ook bespiegel word want, volgens Hasper (Calvyn beginsel voor den zang in den eredienst, bl. 456) was dit 19 plus 3 en volgens Van Andel (Tussen de Regels, bl. 79) was dit ook 19 plus 3. Volgens Van Andel het Calvyn net 5 (Ps. * 
$25,36,46,91$ en 138 ) en 113 onberymd bygedra. Calvyn vind egter nog 13 beryminge van Clement Marot".

Soos ek gesê het, gaan dit eintlik nie oor die 18 of 19 by dr. Kempff nie maar oor die 3 (gesange) wat ek dan sou verswyg het. Het die broeder nie op pladsy 89 gelees dat daar staan ,en 3 gesange" nie?

Dr. Kempff verkwalik my t.o.v. Marnix soos volg: „Dit is wel opvallend dat Van Wyk en Kruger geen verantwoording oor hierdie aspek van Marnix het nie". Volgens Van Andel (bl. 151) kon Marnix se beryming in 1581 op die Sinode van Middelburg geen aanbeveling verdien nie. Dieselfde gebeur op die Partikuliere Sinode van Rotterdam 1582. Slegs die Sinode van Den Haag, die sogenaamde Leicesterse Sinode, het vir die Psalms van Marnix gekies, maar nie sonder voorbehoud nie. Ook hier slaag Marnix nie. Selfs na sy hersieningspoging misluk Marnix se beryming omdat Datheen se beryming te populêr was. Dr. K., glo ek, bewys niks om na 150 (Psalms) plus 21 (Gesange) te verwys, wat vir geen sinode of gemeente aanvaarbaar was nie. Daarom het ek dit weggelaat. Ook dr. Kempff se raad aan Kruger, m.b.t. sinodebesluite op bl. 96-109 bewys nog nie dat Kruger se stellings verkeerd is nie.

Ek wil tog ook iets sê na aanleiding van dr. K. se kritiek oor Calvyn en Amos 5 veral t.o.v.: "Waar Calvyn self buite die Psalmbundel vir die kerksang gegaan het". Calvyn se eerste bundel het wel drie gesange ingesluit. Die Psalmbundel van Marot en Beza wat op aandrang van Calvyn in 1561 voltooi is en Calvyn s'n vervang het, het volgens Van Andel (bl. 81, 82) uit 150 Psalms bestaan en die Lofsang van Simeon (deur Marot). Die feit dat die Lofsang van Simeon in die Psalmbundel was, wil nog nie sê dat Calvyn dit laat sing het nie. Altans nie volgens bewyse van Doumerque, Van Andel, Douen, en Heyns nie. (Vgl. 45, 46 en 47 van my boek).

Ek kan nie nalaat om $K$. se veralgemening in die laaste paragraaf ongesiens te laat verbygaan nie. Dr. Kempff wil my van kettery beskuldig in die hantering van die Skrif, want watter ander afleiding kan ek uit die volgende maak: „My eintlike beswaar teen Van Wyk se bewysvoering is dat dit ' $n$ sirkelberedenering bevat eers veronderstel hy om sekere sake in die Skrif te vind (of hy lees dit daarin) en vervolgens lei hy dit daaruit af". Reeds in die eerste paragraaf van my boek maak ek die stelling dat Psalms gesing moet word in die erediens omdat God dit gebied in Sy Woord en dit bewys ek histories en skriftuurlik. Kort tevore verwys dr. K. na bladsy 31, waar dit gaan oor die eenheid van die genadeverbond en Christus se Testament. Ek vra die broeder beleefd om my hier op my dwaling te wys. Ek het nooit voorgegee dat ek 'n teoloog is nie, maar sal baie graag van hom as teoloog (of redakteur?) wil leer.

Ten slotte 'n aanmerking oor die laaste vier reëls van die resensie nl. dat ons moet vashou aan wat die Gereformeerde vaders oor eeue gesê het: "Bly vir kerksang by dit waarvan teks in die Bybel gegee is...." Hoe verdedig u dan Skrifberymings 27, 49 en 50 wat nie in die Skrif voorkom nie? 


\section{In die Skriflig}

Wie kies die tekste wat in die Bybel voorkom? Word dit maar oorgelaat aan die willekeur van mense? Gevolglik is dit geen wonder dat ons Christus se visitasierapporte aan die sewe gemeentes in Openbaring aan die Groot Visitator terugsing nie. Daarom is ons verleë met historiese tekste soos die Lofsange van Maria en Simeon en die Skrifberymings uit Openbaring. Dan word ons ook eksemplaries in ons lied en is ons sang nie meer Christussentries nie, maar word die mens soos by Maria en Simeon die middelpunt van ons sang. Holwerda sê dat die uniekheid van die teks verlore gaan want dit word uit sy historiese verband uitgelig en oorgeplant in ' $n$ vreemde (ander) omgewing. Dan laat ons nie reg geskied aan die teks nie, maar aan ' $n$ bykomstigheid van die teks. Dan soek ons 'n analogie tussen Johannes op Patmos en wat hy in die boek Openbaring gesien het en ons. Dan sing ons: „Hy het my die stad getoon..." Nee, die uniekheid van die gebeure soos Johannes, Maria en Simeon dit ondervind het, kan selfs dr. Kempff nooit belewe nie. Met die Psalms is dit anders gesteld, daarvan getuig my boek. Lees dit maar weer na. Ten slotte, die Saligsprekings was tog seker ook nie bedoel gewees om gesing te word nie. 